Article

\title{
Spectrophotometric Determination of Metoprolol Tartrate in Pharmaceutical Dosage Forms on Complex Formation with $\mathrm{Cu}(\mathrm{II})$
}

\author{
Mustafa Cesme, Derya Tarinc and Aysegul Golcu* \\ Department of Chemistry, Faculty of Science and Arts, University of Kahramanmaraş Sütçü Imam, \\ Campuse of Avsar, 46100, Kahramanmaras, Turkey; E-Mail: mustafacesme@msn.com (M.C.) \\ * Author to whom correspondence should be addressed; E-Mail: ag518@ksu.edu.tr; \\ Tel.: +90-344-219-1285; Fax: +90-344-219-1042.
}

Received: 10 March 2011; in revised form: 27 April 2011 / Accepted: 18 May 2011 /

Published: 28 June 2011

\begin{abstract}
A new, simple, sensitive and accurate spectrophotometric method has been developed for the assay of metoprolol tartrate (MPT), which is based on the complexation of drug with copper(II) $[\mathrm{Cu}(\mathrm{II})]$ at $\mathrm{pH} 6.0$, using Britton-Robinson buffer solution, to produce a blue adduct. The latter has a maximum absorbance at $675 \mathrm{~nm}$ and obeys Beer's law within the concentration range $8.5-70 \mu \mathrm{g} / \mathrm{mL}$. Regression analysis of the calibration data showed a good correlation coefficient $(\mathrm{r}=0.998)$ with a limit of detection of $5.56 \mu \mathrm{g} / \mathrm{mL}$. The proposed procedure has been successfully applied to the determination of this drug in its tablets. In addition, the spectral data and stability constant for the binuclear copper(II) complex of MPT $\left(\mathrm{Cu}_{2} \mathrm{MPT}_{2} \mathrm{Cl}_{2}\right)$ have been reported.
\end{abstract}

Keywords: $\beta$-blockers; metoprolol; complexation; spectrophotometry

\section{Introduction}

Metoprolol tartrate (Figure 1) is a selective $\beta$-adrenergic antagonist which is used in the treatment of cardiovascular disorders such as hypertension, angina pectoris, cardiac arrhythmias and myocardial infarction. The drug is quite sensitive, and even a small dose of the drug gives sufficient blockade. The $\beta$-blockers are also misused as doping agents in sports and therefore these drugs have been added to 
the list of forbidden drugs by the International Olympic Committee (IOC) [1]. Therefore the development of an analytical method for the determination of metoprolol tartrate is of great significance. The assay procedures of this drug listed in USP 23 NF18 (1995) [2] and BP (1998) [3] describe titrimetric and spectrophotometric methods [4,5]. In addition, several methods have been reported for quantification of MPT in plasma using high-performance liquid chromatography (HPLC) with UV or fluorescence detection [6-15]. Colorimetric determination of some $\beta$-blocking drugs using carbon disulphide and $\mathrm{Cu}(\mathrm{II})$ ions has been reported [16]. Chloroform was used as an extractant for the formed complex. Many of these methods involve a complex separation step and are non-reproducible. Although complexation reactions are very simple and sensitive, no method for the determination of MPT by this way has been reported. For many years, the use of complexation reactions as an analytical technique was used in lot of areas such as, paints and pigments, textile (mordantion reactions), dye-stuffs and determination of metals and drugs in a lot of materials (pharmaceuticals, biological samples, natural water samples, alloys and natural tea) [17-21]. In this paper, we present a spectrophotometric method for the determination of MPT based on its complexation reaction with $\mathrm{Cu}(\mathrm{II})$, which has then been applied to the analysis of MPT in tablets.

Scheme 1. The structure of MPT.<smiles>COCCc1ccc(OCC(O)CNC(C)C)cc1</smiles>

\section{Experimental Section}

\subsection{Reagents}

MPT and its dosage forms (Beloc Durules) were kindly provided by AstraZenaca Comp. (Istanbul, Turkey). Copper(II) chloride dihydrate and chemicals and solvents were obtained from E. Merck or Carlo Erba. Deionized water was used in order to ensure the absence of any undesirable ions.

\subsection{Physical Measurements}

The carbon, hydrogen and nitrogen analyses were obtained using a Leco 932 CHNS elemental analyser. The infrared spectra $\left(4,000-400 \mathrm{~cm}^{-1}\right)$ were obtained on a Perkin Elmer Spectrum 400 FTIR spectrophotometer using $\mathrm{KBr}$ discs. The electronic spectra were recorded in DMSO on a Perkin Elmer Lambda 45 spectrophotometer. Magnetic susceptibilities were measured by the Gouy method at room temperature using $\mathrm{Hg}\left[\mathrm{Co}(\mathrm{SCN})_{4}\right]$ as calibrant. Molar conductance of the complex was determined in water $\left(\sim 10^{-3} \mathrm{M}\right)$ at room temperature using a Jenway Model 4070 conductivity meter. The metal content of the complex was determined by an ATI Unicam 929 Model AA spectrometer in solutions prepared by decomposing the compounds in aqua regia and then subsequently digesting in concentrated $\mathrm{HNO}_{3} / \mathrm{H}_{2} \mathrm{O}_{2}(1 / 1)$. 


\subsection{Standard Solutions for Spectrophotometric Determination}

A stock solution in water containing $0.2 \mathrm{mg} / \mathrm{mL}$ of MPT was prepared and was diluted as appropriate. This solution was stable for 1 week if kept in the refrigerator. $\mathrm{CuCl}_{2} \cdot 2 \mathrm{H}_{2} \mathrm{O}$ solution $0.5 \%$ $(\mathrm{w} / \mathrm{v})$ was prepared in water.

\subsection{Calibration Curve}

Aliquot volumes of the stock solution containing 8.5-70 $\mu \mathrm{g}$ of MPT were transferred into a series of $10 \mathrm{~mL}$ volumetric flasks. Britton-Robinson buffer $(1 \mathrm{~mL})$ and $\mathrm{CuCl}_{2} \cdot 2 \mathrm{H}_{2} \mathrm{O}$ solutions $(1 \mathrm{~mL})$ were added, mixed well for 20 min while heating using a thermostatically controlled water bath at $35{ }^{\circ} \mathrm{C}$, and then cooled rapidly. The solutions were next completed to the mark with distilled water and the absorbance at $675 \mathrm{~nm}$ was measured against a reagent blank. A calibration curve was plotted and the corresponding regression equation then derived.

\subsection{Procedure for Tablets}

Ten tablets were weighed and pulverized, then a quantity of the powder equivalent to $40 \mathrm{mg}$ MPT was transferred into a small conical flask and extracted with $4 \times 20 \mathrm{~mL}$ of water, filtered into a $100 \mathrm{~mL}$ volumetric flask and completed to the mark with water. Aliquots were transferred into a $10 \mathrm{~mL}$ volumetric flask, than the procedure as described in Section 2.4 was applied. The nominal content of the tablet was determined either from the regression equation or using the calibration graph.

\subsection{Preparation of the Binuclear Cu(II) Complex of MPT}

Methanolic $\mathrm{CuCl}_{2} \cdot \mathrm{H}_{2} \mathrm{O}$ solution $(20 \mathrm{~mL}, 0.171 \mathrm{~g}, 1.0 \mathrm{mmol})$ was added dropwise to a methanolic solution of MPT (20 mL, $0.267 \mathrm{~g}, 1.0 \mathrm{mmol}$ ) according to the literature [22]. The reaction mixture was heated using a thermostatically controlled water bath at $35{ }^{\circ} \mathrm{C}$ for 4 hours. The resulting blue precipitate was filtered, washed with methanol/water $(1: 1 \mathrm{v} / \mathrm{v})$ and dried under vacuum over $\mathrm{P}_{2} \mathrm{O}_{5}$ for several days. Chloride ions in the resulting $\mathrm{MPT}_{2} \mathrm{Cu}_{2} \mathrm{Cl}_{2}$ complex (Scheme 2) were determined by titration with $\mathrm{AgNO}_{3}$. Molecular weight: $730.71 \mathrm{gr} / \mathrm{mol}$, Elemental analysis: (Found/Calculated): C\%: 49.26/49.31, H\%: 6.50/6.62, N\%: 3.40/3.83, Cu\%: 17.01/17.39, M.P. > $200{ }^{\circ}$ C. Solubility: water, DMSO and acetonitrile/water (v/v, 1/1).

Scheme 2. The structure of $\mathrm{MPT}_{2} \mathrm{Cu}_{2} \mathrm{Cl}_{2}$.

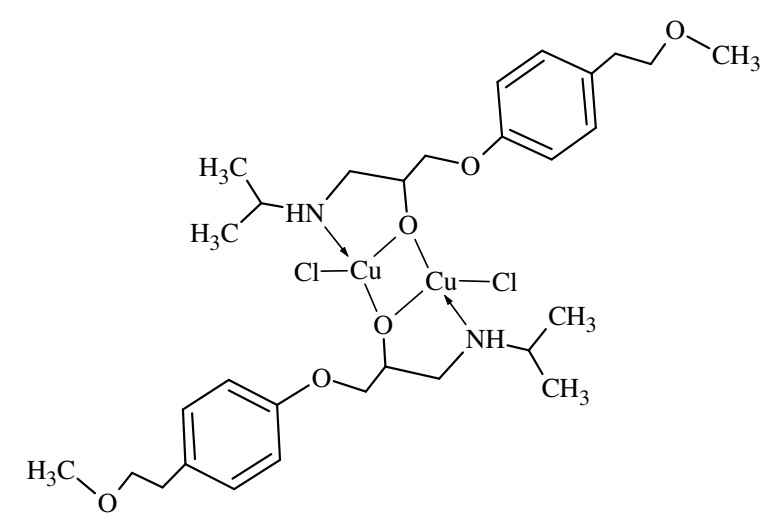




\section{Results and Discussion}

\subsection{Characterization of the Binuclear Cu(II) Complex of MPT}

The goal of this study was to synthesize a Cu(II) complex of the anthypertensive drug MPT, which is as a loop anthypertensive that blocks active sodium chloride transport in the thick ascending limb of Henle's loop. The $[\mathrm{M}]:[\mathrm{L}]$ ratios were varied from 1:10 to $10: 1$ to find out the optimal ratio for complex formation. The effect of heat on the complex formation was investigated by changing the reaction temperature from $+0{ }^{\circ} \mathrm{C}$ to the boiling point of the solvent used. The effect of $\mathrm{pH}$ on the complex formation was investigated; $\mathrm{pH} 6.0$ was found to be the optimal value. The complex formation reactions were carried out with acetate and chloride salts of $\mathrm{Cu}$ (II). The highest yield for the MPT-metal complex was obtained with the chloride salt of $\mathrm{Cu}(\mathrm{II})$. This situation may be due to the role of the substituent groups attached to the benzene ring. Yield of the complex was investigated in different solvents such as water, methanol and acetonitrile. The best yield for the $\mathrm{Cu}$ (II) complex was obtained from water. The effect of the reaction time was also investigated. Reaction mixture was stirred in time intervals from $10 \mathrm{~min}$ to 48 hours. The molar conductance $\left(\Lambda_{\mathrm{M}}\right)$ value (given in parentheses) in DMSO for $\mathrm{MPT}_{2} \mathrm{Cu}_{2} \mathrm{Cl}_{2}$ (21.42) suggests a 1:2 electrolytic complex [22].

\subsection{Infrared Spectra}

In determining the mode of binding of the ligand to the metal ion in the complex. The following three regions of the infrared spectrum have been studied:

(i) The $3459 \mathrm{~cm}^{-1}$ associated with the $\mathrm{v}_{(\mathrm{OH})}$ vibrational mode.

(ii) The 2980 and $2872 \mathrm{~cm}^{-1}$ region associated with the $v_{(\mathrm{NH} 2)}$ and $v_{(\mathrm{NH})}$ modes.

(iv) The region $487-318 \mathrm{~cm}^{-1}$ due to $\mathrm{v}_{(\mathrm{M}-\mathrm{N})}, \mathrm{v}_{(\mathrm{M}-\mathrm{O})}$ and $\mathrm{v}_{(\mathrm{M}-\mathrm{Cl})}$ vibrations.

Figure 1. The infrared spectra of: (a) metoprolol tartrate; (b) binuclear MPT-Cu(II) complex; (c) far infrared of binuclear MPT-Cu(II) complex.

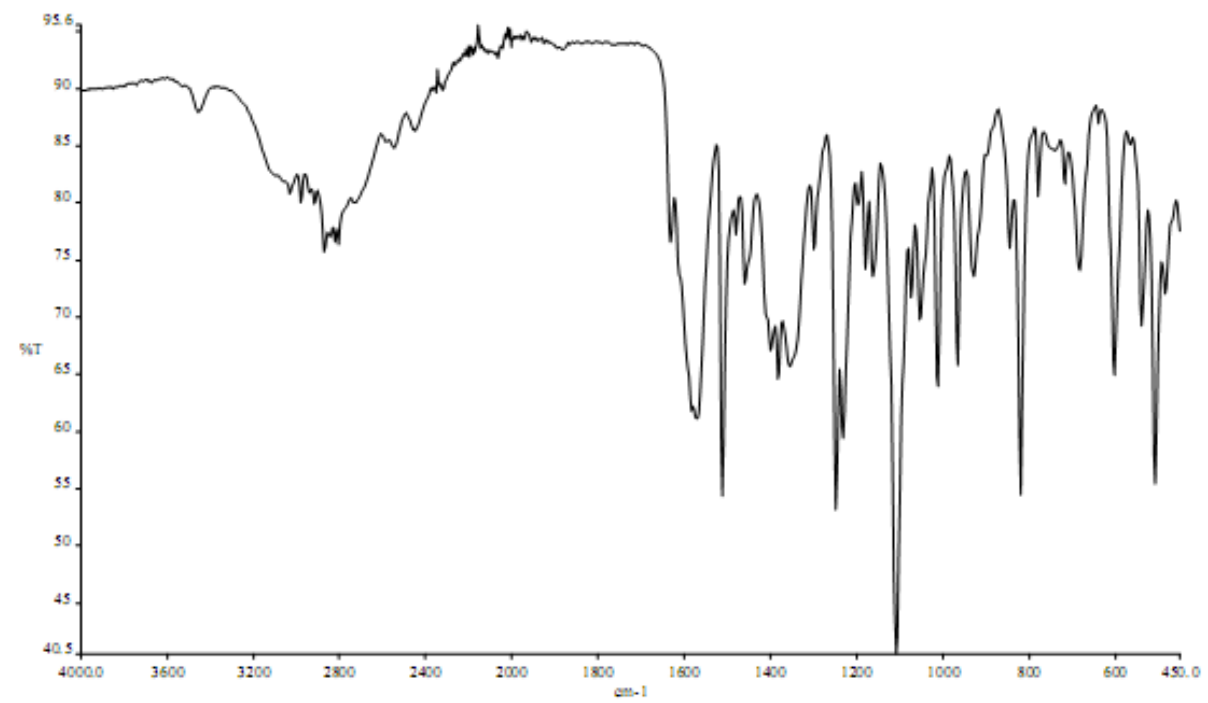


Figure 1. Cont.

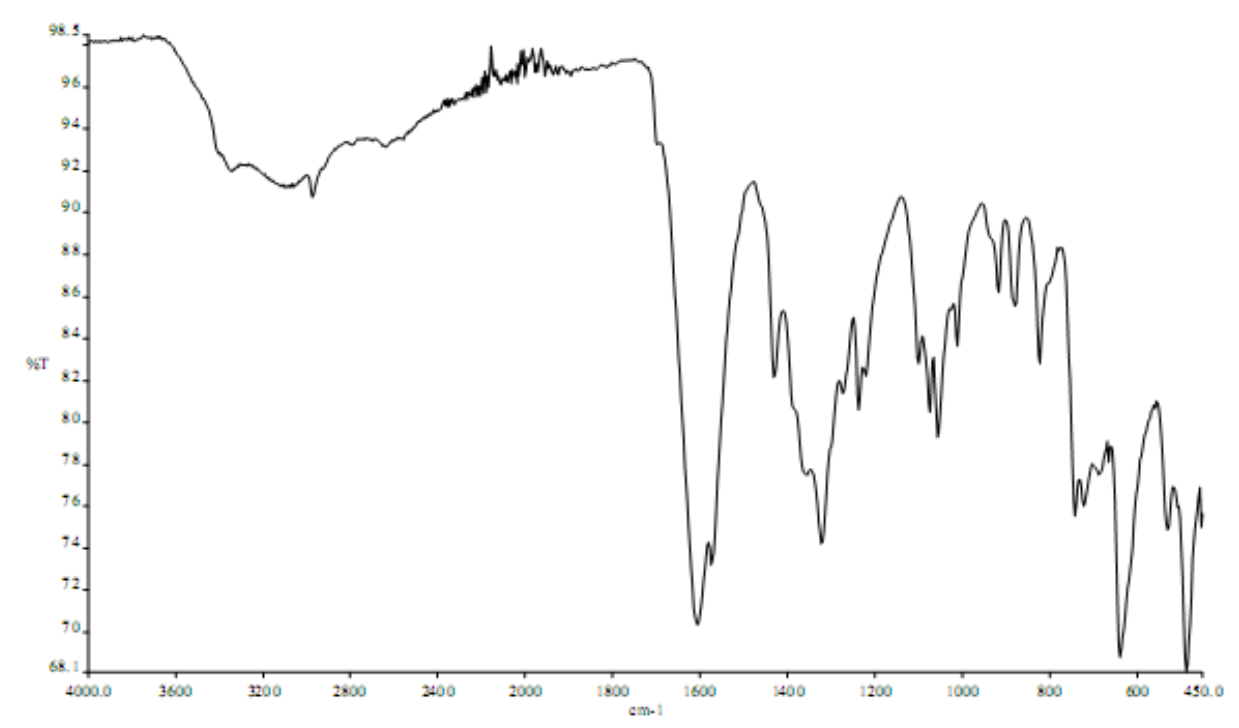

$\mathrm{b}$

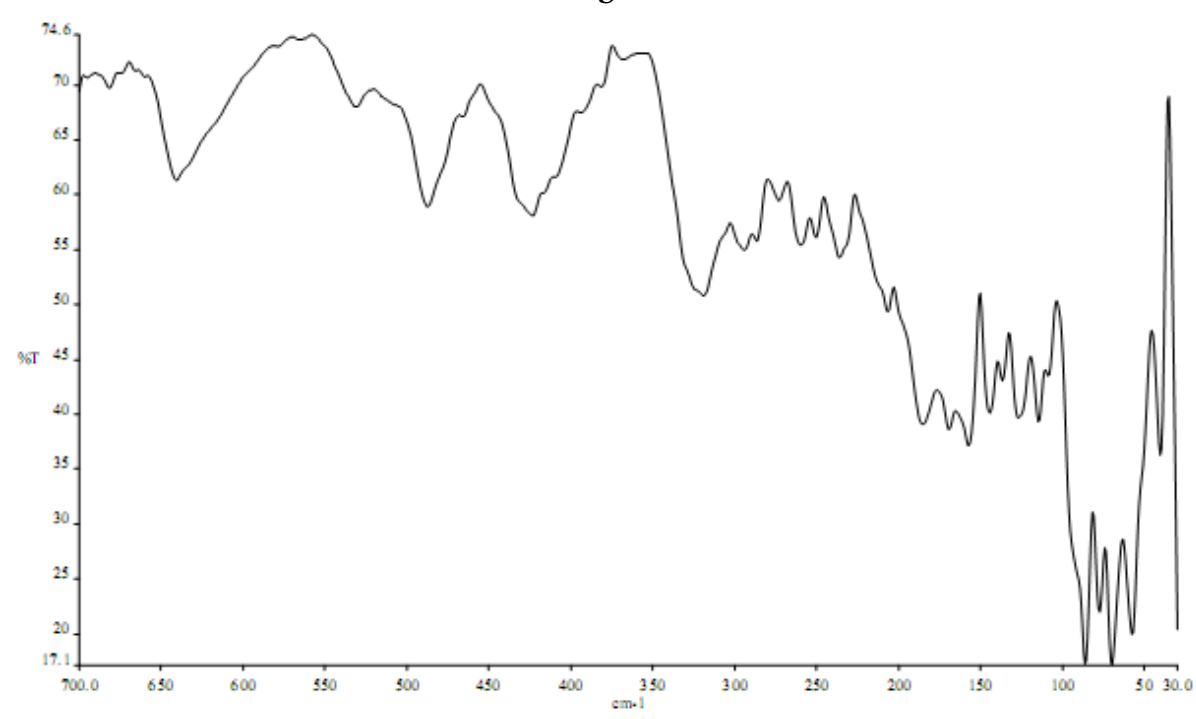

$\mathrm{c}$

The spectra of the free ligand (MPT) showed absorption bands at 3459 and $2980-2872 \mathrm{~cm}^{-1}$ corresponding to the $\mathrm{v}_{(\mathrm{OH})}, \mathrm{v}_{(\mathrm{NH} 2)}$ and $\mathrm{v}_{(\mathrm{NH})}$ stretching frequencies respectively, participating in the formation of intra- and/or intermolecular H-bonds. The binuclear $\mathrm{Cu}$ (II) complex of the MPT shows bands at 2977, 2892-3170 and $3213 \mathrm{~cm}^{-1}$, respectively, for $\mathrm{v}_{(\mathrm{NH} 2)}$ and $\delta_{(\mathrm{NH})}$. No $v_{(\mathrm{OH})}$ bands were observed here because of the deprotonation of the alcohol oxygen. Sharp bands attributable to $v_{(\mathrm{NH} 2)}$ motion may be described as the asymmetric $\left(1606 \mathrm{~cm}^{-1}\right) \mathrm{N}-\mathrm{H}$ stretches, suggesting coordination with the NH group of the ligands (Figure 1) [23]. In the far-IR region, M-N, M-O and M-Cl vibrations were observed at 487,430 and $318 \mathrm{~cm}^{-1}$, respectively, in accordance with literature data [24,25].

\subsection{Electronic Absorption Spectra}

The electronic spectra of the complex was taken in water in order to obviate the effect of the solvent. The spectra of the complex contain some absorption bands in the 811-274 nm range (relatively weak, low-energy bands) which may be assigned to the $\mathrm{d}-\mathrm{d}$ transitions in a square planar configuration. Thesse 
data are in accordance with the assumption for the formation of $\mathrm{M}-\mathrm{N}, \mathrm{M}-\mathrm{O}$ and $\mathrm{M}-\mathrm{CI}$ bonds [26]. The electronic spectra of the complex contain a band with a higher molar absorptivity in the $675 \mathrm{~nm}$ region, assigned to a primarily ligand-centered transition. The band at higher energy is associated with benzene $\pi-\pi *$ transitions $(261 \mathrm{~nm})$. In order to study the stoichiometry of the coloured product the molar ratio between metal ions and drug was determined using Job's continuous variation method [22], which indicated a molar ratio of donor to acceptor of 1:1 for MPT with respect to the drug salt (Figure 2).

Figure 2. The continuous variation plot for the stoichiometry of the reaction of MPT and copper(II).

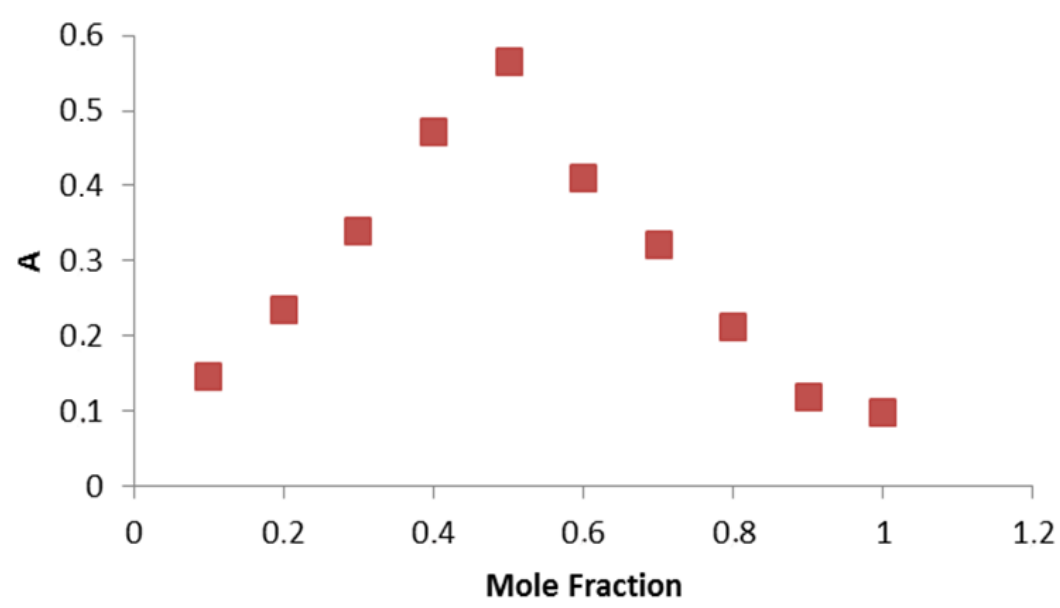

\subsection{Atomic Absorption Spectra}

The ratios of the metal present in the complex was determined by atomic absorption spectroscopy. The complex was decomposed in $\mathrm{HNO}_{3} / \mathrm{H}_{2} \mathrm{O}_{2}(1 / 1)$ and then dissolved in $1.5 \mathrm{~N} \mathrm{HNO}_{3}$. The amount of $\mathrm{Cu}$ was determined. This supports the structure given in Scheme 2 [27-29].

\subsection{Magnetic Measurement}

The magnetic moment (B.M.) of the binuclear $\mathrm{Cu}(\mathrm{II})$ complex, $\left(\mathrm{Cu}(\mathrm{MPT})_{2}(\mathrm{MeOH})_{2}\right)$, was measured at room temperature found to be 1.25; this also supports the proposed structure [30,31]. The magnetic susceptibility of this complex obeys the Curie-Weiss law. Due to steric interactions of the larger size of the ligand the lower coordination number four has been assigned to these complexes [31,32]. The binuclear $\mathrm{Cu}$ (II) complex may thus have the usual tetrahedral structure.

\subsection{Analytical Data}

Copper(II) is a labelling reagent for primary and secondary amines. Several pharmaceutical compounds such as atenolol, acebutolol and propranolol have been determined through this approach [30]. Metoprolol tartrate is secondary aliphatic amino derivative, that was found to react with $\mathrm{Cu}$ (II) with the formation of the binuclear complex resulting in blue adduct. Under the described experimental conditions, the blue adduct has a characteristic absorption spectrum with a maximum absorption at $675 \mathrm{~nm}$.

The different experimental parameters affecting the produced color were extensively studied in order to determine the optimal conditions for the determination of the drug. First, the influence of $\mathrm{pH}$ 
on the absorption was studied. The maximum absorption using Britton-Robinson buffer occurs at approximately $\mathrm{pH} 6$ (Figure 3). Other buffers such as carbonate or phosphate having the same $\mathrm{pH}$ value were studied and compared with Britton-Robinson buffer which was proven to be superior to the others because the absorbance readings were higher. This is due to the hydrolysis of $\mathrm{Cu}$ (II) to $\mathrm{Cu}(\mathrm{OH})_{2}$ using the other buffers. These results are in agreement with those of Miyano et al [33].

Figure 3. Effect of $\mathrm{pH}$ on the development of the complex of MPT (20 $\mu \mathrm{g} / \mathrm{mL})$ with copper(II).

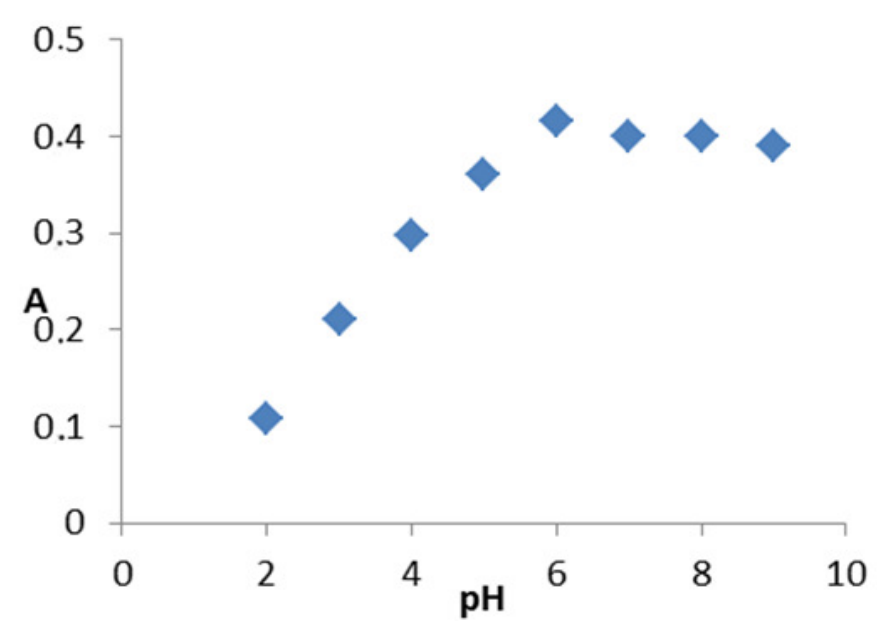

The effect of temperature on the produced adduct was studied, and it was found that heating at $35{ }^{\circ} \mathrm{C}$ for 20 min was better than heating at a higher temperature for a shorter period (Figure 4).

Figure 4. Effect of temperature on the development of the complex of MPT $(20 \mu \mathrm{g} / \mathrm{mL})$ with copper(II).

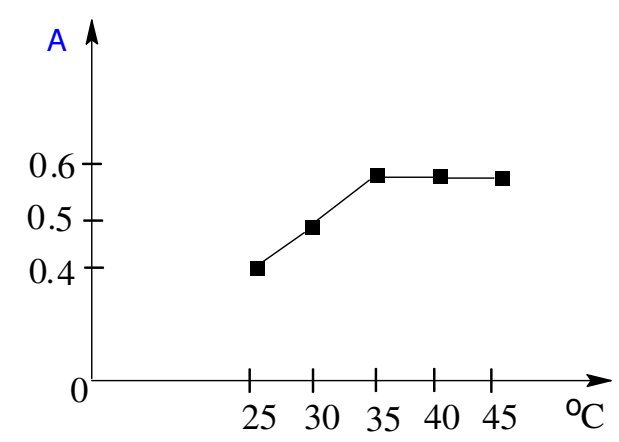

The most important factor affecting the the produced blue color of the adduct was the volume of $\mathrm{Cu}^{+2}$. Figure 5 shows that $1 \mathrm{~mL}$ of $0.5 \% \mathrm{w} / \mathrm{v} \mathrm{Cu}^{+2}$ solution gave maximum sensitivity. Increasing the volume of $\mathrm{Cu}^{+2}$ leads to a decrease in the absorbance, which may be due to the high background absorbance of the reagent. The absorption of the hydrolysis product of $\mathrm{Cu}^{+2}$, namely $\mathrm{Cu}(\mathrm{OH})_{2}$, completely disappeared at $\mathrm{pH}$ less than 4 . Therefore, acidification of the reaction solution prior to the measurement remarkably decreased the background absorbancy without affecting the drug-metal adduct, hence, the sensitivity of the procedure increased. 
Figure 5. Effect of volume of copper(II) $(0.5 \%, \mathrm{w} / \mathrm{v})$ on the development of the complex of MPT $(20 \mu \mathrm{g} / \mathrm{mL})$ with copper(II).

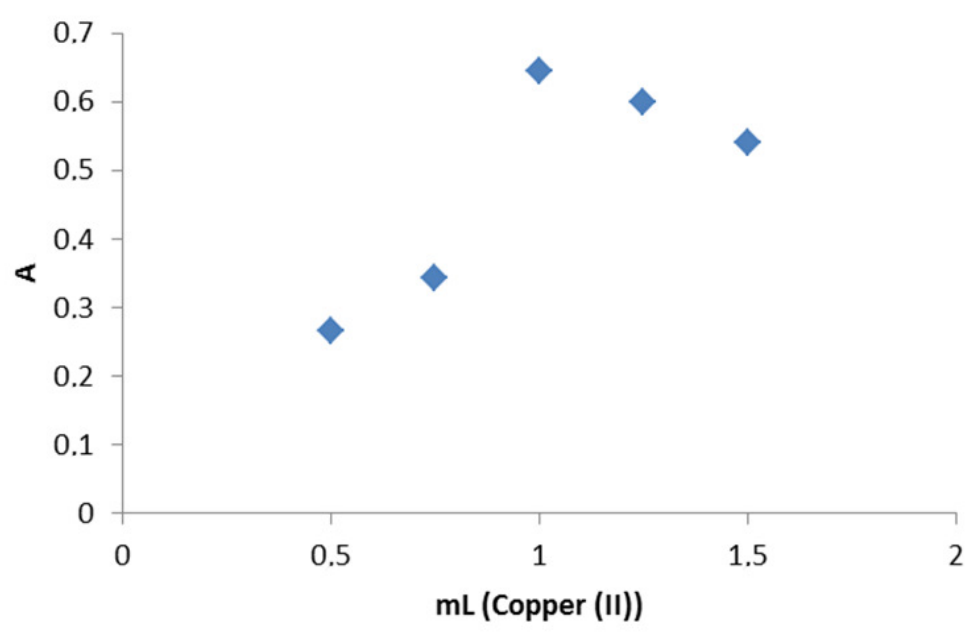

Optimization of the reaction conditions. The spectrophotometric properties of the formed complex as well as the different experimental parameters affecting development and stability of the complex were carefully studied and optimized. For stability studies, the UV spectrophotometer was used. The absorbance values have been measured different times (5-60 $\mathrm{min}$ ). The absorbance value is not change until $50 \mathrm{~min}$. The absorbance value is decreased after $50 \mathrm{~min}(\mathrm{SD} \pm 0.03$ ).

The stability constant of the reaction product $K_{\mathrm{f}}$ was calculated adopting the following formula [34]:

$$
K_{\mathrm{f}}=\frac{A / \mathrm{Am}}{\left(1-A / \mathrm{Am}^{n+1} \mathrm{C}^{n} \mathrm{n}^{n}\right.}
$$

where $A$ is maximum absorbance, Am is the absorbance corresponding to intersection of the two tangests of the curve in Figure 3, $C$ is the concentration corresponding to maximum absorbance, $n$ is the amount of the drug in reaction product. Using this equation, $\mathrm{K} f$ was found to be equal to $1.5 \times 10^{10}$. Under the described experimental conditions, the relation between the absorbance at $675 \mathrm{~nm}$ with the concentration of MPT was linear over the $8.5-70 \mu \mathrm{g} / \mathrm{mL}$ range. Linear regression analysis of the concentration-absorption data gave the following equation:

$$
A=70,000 \mathrm{C}-0.00271, r=0.998
$$

where $\mathrm{C}$ is the concentration in $\mu \mathrm{g} / \mathrm{mL}, \mathrm{A}$ is the absorbance and ' $\mathrm{r}$ ' is the correlation coefficient showing excellent linearity.

The limit of detection (LOD), expressed as the concentration at a signal-to-noise ratio $3 \mathrm{~s} / \mathrm{m}$, was $5.56 \mu \mathrm{g} / \mathrm{mL}$ and the limit of quantification (LOQ), expressed as the concentration at a signal-to-noise ratio $10 \mathrm{~s} / \mathrm{m}, 7.11 \mu \mathrm{g} / \mathrm{mL}[31,32,35]$.

Statistical analysis of the results obtained by the proposed and official methods revealed no significant difference between the performance of the two methods regarding the accuracy and precision as shown in Table 1. 
Table 1. Regression data of the calibration line for quantitative determination MPT by UV method.

\begin{tabular}{lcc}
\hline & Complexation method & UV-spectrophotometric method \\
\hline Measured wavelength $\left(\lambda_{\text {max as nm }}\right)$ & 675 & 274 \\
Linearity range $(\mu \mathrm{g} / \mathrm{mL})$ & $8.5-70$ & $68.4-205.4$ \\
Slope & $0.7 \times 10^{5}$ & $0.25 \times 10^{4}$ \\
Absorbance range & $0.254-0.921$ & $0.276-0.79$ \\
$\varepsilon^{*}$ & 91.900 & 2565 \\
Intercept & -0.0271 & 0.0148 \\
Correlation coefficient $(\mathrm{r})$ & 0.998 & 0.998 \\
LOD $(\mu \mathrm{g} / \mathrm{mL})$ & 5.56 & 8.10 \\
LOQ $(\mu \mathrm{g} / \mathrm{mL})$ & 7.11 & 26.98 \\
Repeatability of absorbance & & 0.21 \\
(RSD\%) & 1.54 & 0.02 \\
Repeatability of wavelength & & \\
(RSD\%) & 0.04 & 0.63 \\
Reproducibility of absorbance & & \\
(RSD\%) & 0.45 & 0.03 \\
Reproducibility of wavelength & & \\
(RSD\%) & 0.12 & \\
\hline
\end{tabular}

* Molar absorption coefficients have been calculated for $30 \mu \mathrm{g} / \mathrm{mL}$.

The proposed method was next applied to the determination of MPT in tablets. Inactive ingredients contained in the tablets are: sodium chloride and titanium dioxide. The results of analysis of tablets are shown in Table 2. Statistical analysis of the results obtained by both the proposed method and direct UV-spectrophotometric method shows no significant difference between the two methods regarding accuracy ( $t$-test) and precision ( $F$-test). The UV spectrophotometric method was validated by us and the results have been given in Table 2 . However, the proposed procedure is advantageous over the reference methods since direct determination of $\mathrm{Cu}$ (II) can be done (if calibration curves of the metal are drawn). Also, the proposed method is sensitive, simple, and accurate. It can be applied for either content uniformity or routine quality control and no expensive laboratory techniques are needed.

Table 2. Assay results from MPT dosage forms and mean recoveries.

\begin{tabular}{|c|c|}
\hline & MPT \\
\hline Product & Beloc Durules \\
\hline Labeled claim (mg) & 200 \\
\hline Amount found (mg) ${ }^{a}$ & 199.50 \\
\hline $\mathrm{RSD} \%$ & 0.004 \\
\hline Bias $\%$ & -0.34 \\
\hline t-test $\left(\mathrm{t}_{\text {theoretical }}=2.31\right)$ & 0.70 \\
\hline F-test $\left(\mathrm{F}_{\text {theoretical }}=2.60\right)$ & 0.22 \\
\hline Added (mg) & 40 \\
\hline Found (mg) ${ }^{a}$ & 40.56 \\
\hline Recovery\% & 100.6 \\
\hline $\mathrm{RSD} \%$ of recovery & 1.30 \\
\hline Bias $\%$ & -0.46 \\
\hline
\end{tabular}

${ }^{\mathrm{a}}$ Each value is the mean of five experiments. 


\section{Conclusions}

A simple, sensitive and accurate spectrophotometric method has been developed for the assay of metoprolol tartrate (MPT), based on the complexation of drug with copper(II) $[\mathrm{Cu}(\mathrm{II})]$ at $\mathrm{pH} 6.0$, using Britton-Robinson buffer solution, to produce a blue adduct. The developed method is more selective, sensitive, reproducible, rapid, cheap and simple than in most of the analogous methods cited in the literature [6-15]. For these reasons, it can be used in routine analysis and can be applied for the determination of MPT in pharmaceutical formulations and biological samples.

\section{Acknowledgements}

The author gratefully acknowledge the funding of this work by the Research Fund (Project No: 2009-4/12) of Kahramanmaraş Sutçu Imam University, Kahramanmaras, Turkey.

\section{References}

1. Martindale, W. Martindale: The Complete Drug Reference, 36th ed.; Pharmaceutical Press: London, UK, 2009.

2. United States Pharmacopoeia: USA 23 NF 18 Inc.; US Pharmacopoeia: USA, 1995.

3. British Pharmacopoeia; Her Majesty's Stationary Office: London, UK, 1998.

4. Hassan, S.S.M.; Abou-Sekkina, M.M.; El-Ries, M.A.; Wassel, A.A. Polymeric matrix membrane sensors for sensitive potentiometric determination of some $\beta$-blockers in pharmaceutical preparations. J. Pharm. Biomed. Anal. 2003, 32, 175-180.

5. Khalil, S.; El-Rabiehi, M.M. Indirect atomic absorption spectrometric determination of pindolol, propranolol and levamisole hydrochlorides based on formation of ion associates with manganese thiocyanate and potassium ferricyanide. J. Pharm. Biomed. Anal. 2000, 22, 7-12.

6. Dongrea, V.G.; Shaha, S.B.; Karmusea, P.P.; Phadkeb, M.; Jadhav, V.K. Simultaneous determination of metoprolol succinate and amlodipine besylate in pharmaceutical dosage form by HPLC. J. Pharm. Biomed. Anal. 2008, 46, 583-586.

7. Sarkar, A.K.; Ghosh, D.; Das, A.; Selvan, P.S.; Gowda, K.V.; Mandal, U.; Bose, A.; Agarwal, S.; Bhaumik, U.; Pal, T.K. Simultaneous determination of metoprolol succinate and amlodipine besylate in human plasma by liquid chromatography-tandem mass spectrometry method and its application in bioequivalence study. J. Chromatogr. B 2008, 873, 77-85.

8. Simmons, B.R.; Stewart, J.T. HPLC separation of selected cardiovascular agents on underivatized silica using an aqueous organic mobile phase. J. Liq. Chromatogr. 1994, 17, 2675-2690.

9. Hubert, P.; Chiap, P.; Moors, M.; Bourguignon, B.; Massart, D.L.; Crommen, J. Knowledge-based system for the automated solid-phase extraction of basic drugs from plasma coupled with their liquid chromatographic determination: Application to the biodetermination of $\beta$-receptor blocking agents. J. Chromatogr. A 1994, 665, 87-99.

10. Mistry, B.; Lesile, J.; Eddington, N.E. A sensitive assay of metoprolol and its major metabolite $\alpha$-hydroxy metoprolol in human plasma and determination of dextromethorphan and its metabolite dextrorphan in urine with high performance liquid chromatography and fluorometric detection. $J$. Pharm. Biomed. Anal. 1998, 16, 1041-1049. 
11. Herring, V.L.; Bastian, T.L.; Lolende, R.L. Solid-phase extraction and direct high-performance liquid chromatographic determination of metoprolol enantiomers in plasma. J. Chromatogr. 1991, 567, 221-227.

12. Uzu, S.; Imai, K.; Nakashima, K.; Akiyama, S. Use of 4-(N,N-dimethilaminosulphonyl)-7-fluoro2,1,3-benzoxadiazole as a labelling reagent for peroxyoxalate chemiluminescence detection and its application to the determination of the $\beta$-blocker metoprolol in serum by high-performance liquid chromatography. Analyst 1991, 116, 1353-1357.

13. Straka, R.J.; Johnson, K.A.; Marshall, P.S.; Remmel, R.P. Analysis of metoprolol enantiomers in human serum by liquid chromatography on a cellulose based chiral stationary phase. $J$. Chromatogr. 1990, 530, 83-93.

14. Phale, M.D.; Hamrapurkar, P.D. A validated and simplified RP-HPLC of metoprolol succinate from bulk drugs. Asian J. Res. Chem. 2009, 2, 119-122.

15. Horai, Y.; Ishizaki, T.; Kusaka, M.; Tsujimoto, G.; Hashimoto, K. Simultaneous determination of metoprolol and [alpha]-hydroxymetoprolol in human plasma and urine by liquid chromatography with a preliminary observation on metoprolol oxidation in Japanese subjects. Ther. Drug Monit. 1988, 10, 428-433.

16. Walash, M.I.; El-Brashy, A.M.; Metwally, M.E.; Abdelal, A. A spectrophotometric determination of penicillamine and carbocisteine based on formation of metal complexes. Farmaco 2004, 59, 493-503.

17. Asan, A.; Isıldak, I.; Andac, M.; Yilmaz, F. A simple and selective flow-injection spectrophotometric determination of copper(II) by using acetylsalicylhydroxamic acid. Talanta 2003, 60, 861-866.

18. Ali, A.E.E. Ternary complexes of copper(II) and their use in the spectrophotometric determination of copper in alloys and rocks. Can. J. Chem. 1993, 71, 1002-1005.

19. Alberti, G.; Biesuz, R.; Profumo, A.; Pesavento, M. Determination of the total concentration and speciation of $\mathrm{Al}(\mathrm{III})$ in tea infusions. J. Inorg. Biochem. 2003, 97, 79-88.

20. Golcu, A.; Yucesoy, C.; Serin, S. Spectrophotometric determination of some beta-blockers in dosage forms based on complex formation with $\mathrm{Cu}(\mathrm{II})$ and $\mathrm{Co}(\mathrm{II})$. Farmaco 2004, 59, 487-492.

21. Golcu, A.; Dolaz, M.; Serin, S. Spectrophotometric determination of propranolol as $\mathrm{Cu}(\mathrm{II}), \mathrm{Ni}(\mathrm{II})$ and Co(II) dithiocarbamate complexes. Turk. J. Chem. 2001, 25, 485-490.

22. Golcu, A. Spectrophotometric determination of furosemide in pharmaceutical dosage forms using complex formation with $\mathrm{Cu}(\mathrm{II})$. J. Anal. Chem. 2006, 61, 748-754.

23. Maccari, R.; Ottana, R.; Bottari, B.; Rotondo, E.; Vigorita, M.G. In vitro advanced antimyco-bacterial screening of cobalt(II) and copper(II) complexes of fluorinated isonicotinoyl-hydrazones. Bioorg. Med. Chem. Lett. 2004, 14, 5731-5733.

24. Bontchev, P.R.; Ivanova, B.B.; Bontchev, R.P.; Mehandjiev, D.R.; Ivanov, D.S. Complexation of $\mathrm{Cu}$ (II) with $\alpha$-[(ethylamino)methyl]-3-hydroxy, benzenemethanol (Effortil). Crystal structure of the mononuclear $\mathrm{Cu}(\mathrm{II})$ complex with Effortil. Polyhedron 2000, 19, 1843-1848.

25. Serin, S. New vic-dioxime transition metal complexes. Tran. Met. Chem. 2001, 26, 300-306.

26. Oberhausen, K.J.; Richardson, J.F.; Buchanan, R.M.; McCusker, J.K.; Hendrickson, D.N.; Latour, J.M. Synthesis and characterization of dinuclear copper(II) complexes of the dinucleating ligand 
2,6-bis[(bis((1-methylimidazol-2-yl)methyl)amino)methyl]-4-methylphenol. Inorg. Chem. 1991, $30,1357-1365$.

27. Golcu, A.; Tumer, M.; Demirelli, H.; Wheatley, R.A. Cd(II) and Cu(II) complexes of polydentate schiff base ligands: Synthesis, characterisation, properties and biological activity. Inorg. Chim. Acta 2005, 358, 1785-1797.

28. Dolaz, M.; Tumer, M.; Golcu, A.; Serin, S. Synthesis and spectrophotometric investigation of a new vic-dioxime ligand and its transition metal complexes. Turk. J. Chem. 2001, 25, 491-500.

29. Goodenough, J.B. Magnetism and the Chemical Bond; Interscience (Wiley): New York, NY, USA, 1963.

30. Golcu, A.; Yucesoy, C.; Serin, S. Synthesis, characterization of metal complexes of acebutolol, atenolol and propranolol-antihypertension drugs. Synth. React. Inorg. Metal. 2004, 34, 1259-1275.

31. Muslu, H.; Golcu, A.; Ozkan, S.A. Electrochemical study of ceftazidime-copper(II) complex: Synthesis, characterization, biological activity and analytical application to pharmaceutical dosage forms. Curr. Anal. Chem. 2010, 6, 299-309.

32. Tarinc, D.; Dogan-Topal, B.; Dolaz, M.; Golcu, A.; Ozkan, S.A. Synthesis, characterization, biological activity and voltammetric behavior and determination of cefaclor metal complexes. Curr. Anal. Chem. 2010, 6, 316-328.

33. Miyano, H.; Toyo'oka, T.; Imai, K. Further studies on the reaction of amines and proteins with 4-fluoro-7-nitrobenzo-2-oxa-1,3-diazole. Anal. Chim. Acta 1985, 170, 81-87.

34. Incezdy, J. Analytical Application of Complex Equilibria; Ellis Horwood Ltd.: England, UK, 1976.

35. Golcu, A.; Dogan, B.; Ozkan, S.A. Anodic voltammetric behaviour and determination of cefixime in pharmaceutical dosage forms and biological fluids. Talanta 2005, 67, 703-712.

(C) 2011 by the authors; licensee MDPI, Basel, Switzerland. This article is an open access article distributed under the terms and conditions of the Creative Commons Attribution license (http://creativecommons.org/licenses/by/3.0/). 